\title{
PROMOTING EQUALITY
}


Also by Neil Thompson

CRISIS INTERVENTION REVISITED

EXISTENTIALISM AND SOCIAL WORK

*ANTI-DISCRIMINATORY PRACTICE (second edition)

*DEALING WITH STRESS (with Murphy, M. and Stradling, S.)

PRACTICE TEACHING IN SOCIAL WORK (second edition)

(with Osada, M. and Anderson, B.)

THEORY AND PRACTICE IN HEALTH AND SOCIAL WELFARE

AGE AND DIGNITY: WORKING WITH OLDER PEOPLE

* PEOPLE SKILLS: A GUIDE TO EFFECTIVE PRACTICE IN THE HUMAN SERVICES

MEETING THE STRESS CHALLENGE: A TRAINING MANUAL (with Murphy, M. and Stradling, S.)

PROTECTING CHILDREN: CHALLENGES AND CHANGE (co-edited with Bates, J. and Pugh, R.)

UNDERSTANDING SOCIAL WORK: PREPARING FOR PRACTICE (in preparation)

*Also published by Macmillan Education 


\section{PROMOTING EQUALITY}

Challenging Discrimination and Oppression in the Human Services

\section{NeIL ThOMPSON}

Foreword by Audrey Mullender

Consultant Editor: Jo Campling

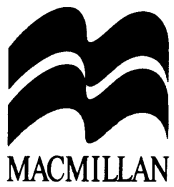


(c) Neil Thompson 1998

Originally published by Macmillan Press Ltd in 1998

Foreword @ Audrey Mullender 1998

All rights reserved. No reproduction, copy or transmission of this publication may be made without written permission.

No paragraph of this publication may be reproduced, copied or transmitted save with written permission or in accordance with the provisions of the Copyright, Designs and Patents Act 1988, or under the terms of any licence permitting limited copying issued by the Copyright Licensing Agency, 90 Tottenham Court Road, London W1P 9HE.

Any person who does any unauthorised act in relation to this publication may be liable to criminal prosecution and civil claims for damages.

The author has asserted his right to be identified as the author of this work in accordance with the Copyright, Designs and Patents Act 1988.

First published 1998

ISBN 978-0-333-65862-8

ISBN 978-1-349-14047-3 (eBook)

DOI 10.1007/978-1-349-14047-3

A catalogue record for this book is available from the British Library.

This book is printed on paper suitable for recycling and made from fully managed and sustained forest sources

$\begin{array}{rrrrrrrrrr}10 & 9 & 8 & 7 & 6 & 5 & 4 & 3 & 2 & 1 \\ 07 & 06 & 05 & 04 & 03 & 02 & 01 & 00 & 99 & 98\end{array}$


Er cof am ewythr John,

dyn arbennig iawn 


\section{CONTENTS}

List of Figures

Foreword by Professor Audrey Mullender

viii

Preface

Acknowledgements

xiii

Introduction

1 Theoretical Foundations 6

2 Power 42

3 Discrimination and Oppression $\quad 77$

4 Health 109

5 Learning from the Past 142

6 The Organizational Context 174

7 Conclusion: Strategies for Promoting Equality 209

References $\quad 228$

Index 244 


\section{LIST OF FIGURES}

1.1 The personal embedded within the cultural

1.2 The cultural embedded within the structural 17

1.3 The ontological security continuum 32

1.4 The subjective-objective dialectic 34

1.5 Emancipatory vs life politics 39

2.1 The interactions of the personal, cultural and structural levels 66

2.2 The relationship between personal empowerment and $\begin{array}{ll}\text { structural change } & 74\end{array}$

$\begin{array}{ll}3.1 \text { Discrimination and oppression } & 79\end{array}$

3.2 Marx's and Weber's approaches to class 90

4.1 The dimensions of health 113

4.2 Wider aspects of child abuse 133

4.3 Medical discourse and the status quo 137

4.4 The health-ontological security dialectic 138

5.1 The Yerkes-Dodson law of adult learning 150

5.2 Degrees of influence 158

$\begin{array}{ll}5.3 \text { Using legislation } & 159\end{array}$

5.4 The balance between defeatism and unrealistic expectations 170

5.5 The 'Polo mint' approach 171

6.1 The subjective-objective dialectic within an organization 188

6.2 The two-dimensional model of stress 198

6.3 The three-dimensional interactive model of stress 198

6.4 Promoting positive change in organizations 202

$\begin{array}{ll}7.1 & \text { PCS levels of empowerment } \\ & 212\end{array}$ 


\section{FOREWORD}

This is, in many ways, the book we have been waiting for in the human services. A generation of social work students has already graduated on Neil Thompson's 'PCS' model - that is, the personal, cultural and social analysis which explains so clearly the need to consider the discrimination and oppression affecting service users' lives on a much wider level than the person-to-person interactions of family life or of practitioner-service user encounters.

To date, however, even in social work - where at least a nod in the direction of 'ADP' (anti-discriminatory practice) has become a widespread expectation - the need to explore what we mean when we talk about power and powerlessness has too often been glossed over. As a result, intervention, instead of devoting itself to 'promoting equality' (in the words of Neil Thompson's new title) has contented itself with merely talking about it. We needed the nudge out of complacency that this book will provide.

A major contribution of this text, too, is to extend the anti-discriminatory enterprise beyond social work into the human services more generally. Increasingly, it is being recognized that the major 'helping professions' - across health, welfare, education, community justice have so much in common that theorizing should straddle them all, particularly in relation to organizational and management issues. Neil Thompson's areas of interest (the organizational climate, for example) make him an ideal person to engage with this broader task, and what he offers here will be as relevant on MBA programmes in the public services as it will in qualifying training for nurses and social workers.

Breadth is essential in relation to anti-oppressive thinking itself. There are specialist literatures emerging not just from the struggles against each of the major oppressions - the 'antis' of anti-sexism, antiracism, anti-homophobia, and so on, but also from within each per- 
spective. Thus, we need to be seeking out feminist writings, works by gay and lesbian authors, all forms of literature grounded in black perspectives, the theorizing of the disabled people's movement, materials that celebrate becoming older and enjoying advanced age or that reflect the experience of living in poverty, and explorations of the interactions and overlaps between all of these.

It has remained surprisingly difficult, however, to find texts that offer an overarching analysis of how we can conceptualize the operation of oppression in all its complexity, and how we can best think about tackling it. Neil Thompson has come to occupy that ground with his Anti-Discriminatory Practice and, with this new book, he has 'done it again'! This is a more developed yet easily digested text which will, I am sure, quickly become essential reading.

AUdREY MULLENDER Professor of Social Work University of Warwick 


\section{Preface}

The need to take seriously issues of inequality, discrimination and oppression continues to be a pressing one, as human services workers each day come face to face with the negative effects of such problems. This book will not provide easy answers or formula solutions, but is intended to be of value in terms of the theoretical analysis presented and the constant links between the theory base and the realities of day-to-day practice. It is presented not as a comprehensive theoretical exposition, nor as a 'cookbook' of recipes as to how to practise in ways that seek to challenge inequality and disadvantage. Rather, it represents an attempt to integrate theory and practice by exploring a range of theoretical issues and relating these to the practice context - with a view to contributing to high-quality practice informed by clear principles and an appreciation of the complexities involved.

Practitioners, managers, educators and policy-makers in the human services face a number of challenges, due to the demanding nature of responding to human problems in a range of settings and contexts. Having to take account of the need to promote equality and recognize the significance of discrimination and oppression in people's lives is therefore an additional pressure in what already tend to be highly pressurized work situations. However, my argument here is that this additional challenge should be seen as a core element of good practice, for to practise without addressing issues of inequality is to run the risk of exacerbating the situation - reinforcing existing patterns of disadvantage. A central theme of the book, then, is the importance of addressing issues of inequality, discrimination and oppression in all aspects of theory, policy and practice in order to make sure that our efforts are part of a process of promoting equality, rather than one of adding to or intensifying existing burdens of oppression.

Staff in the human services are in a pivotal position as far as dis- 
crimination and inequality are concerned. Whether we are nurses, social workers, teachers, youth workers, police or probation officers, housing officers, counsellors, advisors or members of any other branch of the human services, we are likely to work with people who are discriminated against in one or more ways, and our actions could be of benefit to them in dealing with the challenges their circumstances present, or the steps we take could have the opposite effect of further marginalizing and disempowering already disadvantaged groups, for example by reinforcing negative stereotypes. Human services practice can be empowering or it can, in itself, be a form of oppression. This book is intended as an aid to people involved in the human services to appreciate the significance of these issues and to be better equipped to play a part in making sure that practice contributes to empowerment, and not to oppression.

NEIL THOMPSON 


\section{ACKNOWLEDGEMENTS}

I have once again been fortunate to have the good will and support of a number of people who have been prepared to offer critical comment on all or part of the earlier draft of the book. Colin Richardson, Fellow of Keele University, John Bates and Richard Pugh of North East Wales Institute, Beth Humphries of Manchester Metropolitan University, and Brid Featherstone of the University of Bradford have all contributed to improving on the original text. I am extremely grateful to them all. I am also very grateful indeed to Professor Audrey Mullender for being so kind in providing the Foreword. Jo Campling deserves both thanks and credit for her continued support, as does Susan Thompson for the major contribution she makes to all of my work in one way or another.

I also wish to extend my thanks to Jane Boylan and Bernard Moss for their friendship and stimulating company - a very valuable contribution to my work at a time when I needed it - and to Joyce Thompson for her sustained efforts in typing the manuscripts.

NEIL THOMPSON 